\title{
Erratum to: A linear genetic programming approach for the prediction of solar global radiation
}

\author{
Hassan Shavandi · Sara Saeidi Ramiyani
}

Published online: 15 August 2012

(C) Springer-Verlag London Limited 2012

Erratum to: Neural Comput \& Applic

DOI 10.1007/s00521-012-1039-6

In the original publication, the name of second author was published incorrectly. The correct name should be "Sara Saeidi Ramiyani”.

The online version of the original article can be found under doi: 10.1007/s00521-012-1039-6.

H. Shavandi $(\bowtie) \cdot$ S. Saeidi Ramiyani Department of Industrial Engineering, Sharif University of Technology,

P.O. Box 11155-9414, Tehran, Iran

e-mail: shavandi@sharif.edu

S. Saeidi Ramiyani

e-mail: sara.saeedi@hotmail.com 